\title{
Socioeconomic Perspectives to Arable Crop Farmer-Herder Conflicts in Ebonyi North Zone, Ebonyi State, Nigeria
}

\author{
Umeh, G.N ${ }^{1}$, Chukwu, V.A ${ }^{2}$ \\ ${ }^{1}$ Department of Agricultural Economics, Management and Extension, Ebonyi State University, P.M.B 053, Abakaliki, Ebonyi State, Nigeria \\ ${ }^{2}$ Ebonyi State Agricultural Development Programme (EBADEP) P.M.B 040, Abakaliki, Ebonyi State, Nigeria
}

\begin{abstract}
Socioeconomic Perspectives to Arable Crop Farmer-Herder conflicts in Ebonyi North Zone of Ebonyi State, Nigeria was studied. A combination of purposive, systematic and simple random sampling techniques was employed in the selection of 172 respondents (160 farmers and 12 herdsmen). Primary data were sourced through field survey; with the aid of a well-structured questionnaire and interview schedule. Both descriptive and inferential statistics were employed in data analysis. Result showed that majority (96.3 percent) of the farmers were males and belong to age bracket of 51-60 years (29.4percent) and were mostly married (83.8\%). Further analysis showed that all the herdsmen were males with no formal education. The age of majority (31.3 percent) ranged between 31-40 years while 87.50 percent were married. The result of probit analyses showed Chi-square values of 5346.00 and 1283.124 for farmers and herders respectively. This shows the goodness of fit of the models. The overall model was statistically significant $(P<0.05)$, implying that the independent variables asserted great influence on the frequency of conflicts with the herdsmen. Most of the independent variables were statistically significant and met a priori expectations. Two null hypotheses tested were rejected, implying that the socio-economic characteristics of the farmers and herdsmen significantly influenced their frequency of conflicts. The level of human casualty among the two conflicting groups within the period was low. However, the economic loss was huge on the two parties. While the farmers lost a lot of crops and farms to the conflicts the herdsmen lost several cattle and sheep as a result of the conflicts. Crops mostly affected were cassava (89\%) and rice (55\%). Herders seemed to have incurred more economic lost in monetary terms than the farmers. Social cost of the conflict among the farmers and the herdsmen include loss of peace and co-existence among the groups, breakdown of established friendship between the groups, perpetual fear of attack and loss of family means of livelihood. It was recommended that peace and conflict resolution committee that include representatives of farmer and herder communities be instituted by the state government.
\end{abstract}

Keywords: Conflicts, Fulani Herdsmen, Arable Crops Farmers, Socio-economic Perspective, Ebonyi State, Nigeria.

\section{Introduction}

Agricultural production in Nigeria is dominated by ruralbased small scale arable producers, which account for about $80 \%$ of total food requirement of the Nation. The arable crop farmers are faced with both natural and social problems such as abnormal rainfall, drought, infestation etc.

It is probably unarguable that resource ownership and utilization have for centuries directly and indirectly explained the causes of many conflicts involving man since time in the past (Getu and Kolawole, 2002). Among competing resources, however, land resources has remained an over whelming source of conflicts among various users groups as well as individuals at varying thresholds. In particular, conflict between farmers and herdsmen in the use of agricultural land is becoming fiercer and increasingly widespread in Nigeria, largely due to intensification of production activities that are necessitated by increasing human population (Fosona and Omojola, 2005).

The resultant increase in competition for arable land has often times resulted to serious manifestation of enmity and social conflicts among the two opponents in many parts of Nigeria. Fasona and Omojola (2005) pointed out that, the herdsmen arable crop farmers conflicts have not only brought about high level of insecurity but have also demonstrated high potential to the food crisis in Nigeria and other countries because of loss of human lives, animal, crops and other valuable properties. For instance, the conflict in Darfur region of Sudan started as a resource-based conflict between herdsmen and farmers before transforming into a full-blown war that has claimed over 200,000 lives and rendered over a million people homeless. Just as in the Sudan, farming and cattle-herding respectively are predominantly associated with distinct ethnic groups. Fasona and Omojola (2005) newspaper publication revealed that among conflicts/crises recorded in Nigeria between 1991 and 2005, farmers-herdsmen conflicts accounted for 35\% of the clashes.

Adebayo (1997) recorded that the clashes between herdsmen and crop farmers has existed since the origin of agriculture, although the prevalence of tse tse fly and low settlement densities kept the incidence of conflicts at a low rate until the twentieth century (Blench, 1999). The introduction of cheap trypanocides in West Africa and other veterinary drugs increased herd number to levels that made herdsmen to seek pastures outside their traditional ecological areas (Adebayo, 1997). In the same vein, improved human health also increased overall population and pressure on arable farm land. In West Africa, the two groups co-exist, especially through the exchange of crop residues for manure typical in semi-arid and sub-humid zones. Ebii (2004) observed that, the expansion of riverine and low bottom (fadama) cultivation since the 1980s has made the herders and crop farmers to compete directly for access to river banks with a consequent increase in clashes. In Nigeria, the 


\section{International Journal of Science and Research (IJSR) \\ ISSN (Online): 2319-7064 \\ Index Copernicus Value (2013): 6.14 | Impact Factor (2015): 6.391}

political control of local government by farming population representative has increase pressure to invade land kept for grazing and also herdsmen denied of high productivity. Although Bermadet (1999) observed that the conflict has now been included into a broader dichotomy of religion and conflicts over access to resources are now framed in religious tone. The availability of modern weapons has also increased the intensity and violence of these disputes in many parts of the country.

The necessity to provide food of crop and animal origin, as well as raw materials for industry and export to meet evergrowing demands, has led to both intensification of land use. The competition between these two agricultural land usergroup, however, has often times turned into serious manifestation of hostilities and social friction in many parts of Nigeria. Nweze (2005) observed that, the causes of crop farmers-herdsmen conflicts were due to lack of consensus among both groups and also not considering their mutual benefits.

Crop farmers-herdsmen conflicts have been of great negative effects regardless of the causes. The range includes economic effects such as loss of yield and income/to physical like farm destruction and home body injury or death of family member (s). Others include sociopsychological effects such as emotional tiredness and job dissatisfaction (Nweze, 2005). The crop farmers-herdsmen conflicts have attracted considerable theoretical and empirical analyses due to their causes and effects; but the socio-economic perspectives of the conflicts have not received adequate and satisfactory attention in literature. Therefore, there is urgent need to critically examine the socio-economic perspective of farmer-herder conflict with a view to reforming co-existence and peace between the two conflicting groups on sustainable basis. The study therefore sought to answer the following research questions: What are the socioeconomic characteristics of the respondents (farmers and herdsmen)? What is the relationship between the socio economic characteristics of the respondents and their frequency of conflict?

What are the socio-economic effects of farmer-herdsmen conflicts in the zone in the past five years (2010-2015)?

\section{Objectives of the Study}

The broad objective of this study is to analyze the socioeconomic perspectives to arable crop farmer-herder conflicts in Ebonyi North Zone, Ebonyi State, Nigeria. The specific objectives were to:

1) Describe the socio-economic characteristics of the respondents;

2) Analyze the relationship between the socio-economic characteristics of the respondents and their frequency of conflicts; and

3) Identify socio-economic effects of farmers-herdsmen conflicts in the zone in the past five years (2010-2015).

\section{Hypotheses}

Two null hypotheses were tested.
Ho$_{1}$ : The socio-economic characteristics of arable crop farmers have no significant relationship with frequency of conflicts with herdsmen.

$\mathbf{H o}_{2}$ : The socio-economic characteristics of herdsmen have no significant relationship with frequency of conflicts with arable crop farmers.

\section{Methodology}

This study was conducted in Ebonyi North Zone of Ebonyi State, Nigeria, which lies appropriately on latitude 70.30 'N and longitude 50.40'E and 50.45' $\mathrm{E}$ in the South East geopolitical zone of Nigeria. Purposive sampling technique was adopted in the selection of two (2) autonomous communities that are endemic to herdsmen/crop farmers' conflict from each of the four (4) local government areas in the zone. Simple random sampling techniques were used to select five (5) villages from each of the selected communities to give a total of (40) villages. From each village, four (4) arable crop farmers were systematically selected to give a total of one hundred and sixty (160) farmers. However, two Fulani cattle rearers were also randomly selected from each of the selected eight (8) autonomous communities to give a total of sixteen (16) Fulani herdsmen. Thus, a total of one hundred and seventy two (172) respondents were used for the study. Primary data was sourced by the use of structured questionnaire and interview schedule. Both descriptive and inferential statistics were employed in data analysis. Descriptive statistics such as frequency distribution, percentages and means were used to analyze objective I and III; while objective II was analyzed using probit regression analysis. The null hypotheses were tested with F-test at 5 percent level of significance.

\section{Model Specification}

Relationship between the Socioeconomic Characteristic of Farmers and Frequency of Conflicts with Herdsmen (Implicit Function)

$\mathrm{Y}=\mathrm{a} 0+\mathrm{a} 1 \quad$ AGE $+\mathrm{a} 3 \quad \mathrm{MST}+\mathrm{a} 4 \quad \mathrm{AFI}+\mathrm{a} 5 \quad \mathrm{EDS}+\mathrm{a} 6+\mathrm{HS}+\mathrm{a} 7$ $\mathrm{Mcs}+\mathrm{a} 8 \mathrm{HS}+\mathrm{a} 9 \mathrm{HE}+$

et------implicit function

Where

$\mathrm{Y}=\quad$ Frequency of conflicts (number of times the respondents were involved in conflicts with the herdsmen)

$\mathrm{a} 0=\quad$ Constant or intercept

a1-a9= Regression coefficient

$\mathrm{AGE}=$ Age (years)

GEN $=$ Gender (male-2, female-1)

$\mathrm{MS}=\quad$ Marital Status (Dummy married-1, single 2)

$\mathrm{AFI}=\quad$ Annual farm Income from crops $(\mathrm{N})$

$\mathrm{EDS}=$ Educational Status (number of years in school)

$\mathrm{HS}=$ Household size (number of persons living in the same household)

MCS $=$ Membership of Cooperative society (dummy) $(\mathrm{Yes}=1, \mathrm{No}=0)$

$\mathrm{FS}=$ Farm size (Number of hectares)

$\mathrm{FE}=$ Farming Experience (years of farming)

et $=$ Stochastic error term 


\section{International Journal of Science and Research (IJSR) \\ ISSN (Online): 2319-7064}

Index Copernicus Value (2013): 6.14 | Impact Factor (2015): 6.391

Relationship between the Socioeconomic Characteristic of Herdsmen and Frequency of Conflicts with Farmers (Explicit Function)

$\mathrm{Y}=\mathrm{a} 0+\mathrm{a} 1 \quad \mathrm{AGE}+\mathrm{a} 3 \quad \mathrm{MST}+\mathrm{a} 4 \quad \mathrm{AFI}+\mathrm{a} 5 \quad \mathrm{EDS}+\mathrm{a} 6+\mathrm{HS}+\mathrm{a} 7$ $\mathrm{Mcs}+\mathrm{a} 8 \mathrm{HS}+\mathrm{a} 9 \mathrm{HE}+$

et------Explicit stochastic form

Where:

$\mathrm{Y}=\quad$ Frequency of conflicts (number of times the respondents were involved in conflicts with the farmers)

$\mathrm{a} 0=\quad$ Constant or coefficient

a1-a9 $=$ regression coefficients

$\mathrm{AGE}=$ Age (years)

$\mathrm{GEN}=$ Gender (male-2, female-1)

$\mathrm{MS}=\quad$ Marital Status (Dummy) married-1, single-2)

$\mathrm{AFI}=\quad$ Annual farm Income from Livestock $(\mathrm{N})$

$\mathrm{EDS}=$ Educational Status (number of years in school)

$\mathrm{HS}=$ Household size (number of persons living in the same household)

Mcs $=$ Membership of Cooperative society (dummy) $(\mathrm{Yes}=1, \mathrm{No}=0)$

$\mathrm{HS}=\quad$ Herd size (Number of animals)

$\mathrm{HE}=$ Herding Experience (years of animal rearing)

et $\quad=\quad$ Stochastic error term

\section{Hypothesis Testing}

The null hypotheses were tested with F-test as shown below:

F-cal $\quad=\quad \underline{\mathrm{R}^{2}(\mathrm{~N}-\mathrm{K})}$

$$
1-\mathrm{R}^{2}(\mathrm{~K}-1)
$$

Where:

$\begin{array}{lll}\mathrm{R}^{2} & = & \text { Co-efficient of multiple determination } \\ \mathrm{N} & = & \text { Sample size } \\ \mathrm{K} & = & \text { Number of variables }\end{array}$

Decision Rule: If F-cal $>$ F-tab, reject the null hypotheses otherwise accept the alternatives.

\section{Results and Discussion}

The result and discussion of the findings were presented in line with the study objectives.

Socio-economic Characteristics of the Farmers and Herders

The result of the socio-economic characteristics of the farmers and herders are shown in Tables 1 and 2 .

Table 1: Percentage Distribution of the Socio-economic Characteristics of the Farmers $(N=160)$

Socio-economic Characteristics Frequency Percentage Mean $\bar{x}$

\begin{tabular}{|c|c|c|c|}
\hline Sex & & & \\
\hline Male & 154 & 96.3 & \\
\hline Female & 6 & 3.8 & \\
\hline Age & & & \\
\hline$<20$ & 3 & 1.9 & \\
\hline $21-30$ & 30 & 18.8 & \\
\hline $31-40$ & 17 & 10.6 & \\
\hline $41-50$ & 44 & 27.5 & 45.4 \\
\hline $51-60$ & 47 & 29.4 & \\
\hline$>61$ & 19 & 11.9 & \\
\hline Marital Status & & & \\
\hline \multicolumn{2}{|l}{}
\end{tabular}

\begin{tabular}{|c|c|c|c|}
\hline Single & 22 & 12.8 & \\
\hline Married & 134 & 83.8 & \\
\hline Widowed & 4 & 2.5 & \\
\hline \multicolumn{4}{|l|}{ Level of Education } \\
\hline No formal education & 6 & 3.8 & \\
\hline Primary education & 43 & 26.9 & \\
\hline Secondary education & 36 & 22.5 & 6 \\
\hline OND/NCE & 39 & 24.4 & \\
\hline $\mathrm{HND} / \mathrm{BSC}$ & 31 & 19.4 & \\
\hline M.Sc and above & 5 & 3.1 & \\
\hline \multicolumn{4}{|l|}{ Household size } \\
\hline $1-5$ & 27 & 16.9 & \\
\hline $6-10$ & 72 & 45.0 & \\
\hline $11-15$ & 35 & 21.9 & 10 \\
\hline $16-20$ & 15 & 9.4 & \\
\hline Above 21 & 11 & 6.9 & \\
\hline \multicolumn{4}{|l|}{ Farm size } \\
\hline$<50$ & 9 & 5.6 & \\
\hline $0.6-1.0$ & 29 & 5.6 & \\
\hline $1.1-1.5$ & 48 & 30.0 & 1.6 \\
\hline $1.6-2.0$ & 26 & 16.3 & \\
\hline $2.1-2.5$ & 23 & 14.4 & \\
\hline Above 2.6 & 25 & 15.6 & \\
\hline \multicolumn{4}{|c|}{ Farming Experience (years) } \\
\hline$<10$ & 4 & 2.50 & \\
\hline $11-20$ & 28 & 17.50 & \\
\hline $21-30$ & 36 & 22.50 & 33 \\
\hline $31-40$ & 30 & 18.80 & \\
\hline Above 41 & 62 & 38.80 & \\
\hline \multicolumn{4}{|l|}{ Annual farm income (N) } \\
\hline$<\mathrm{N} 100,000$ & 6 & 3.80 & \\
\hline $\mathrm{N} 101,000-\mathrm{N} 200,000$ & 44 & 27.50 & $\mathrm{~N} 263,000$ \\
\hline $\mathrm{N} 201,000-\mathrm{N} 300,000$ & 44 & 27.50 & \\
\hline $\mathrm{N} 301,00-\mathrm{N} 400,000$ & 56 & 35.00 & \\
\hline Above N401,000 & 10 & 6.30 & \\
\hline \multicolumn{4}{|c|}{ Membership of Cooperatives } \\
\hline Member & 121 & 75.60 & \\
\hline Non-member & 39 & 23.40 & \\
\hline Total & 160 & 100 & \\
\hline
\end{tabular}

Source: Field Survey, 2015.

The result in Table 1 showed that 96.3 percent of the farmers involved in the conflicts were males; while very few 3.8 percent were females. This corroborates Tonah (2006) who reported that men readily involve in herdsmen conflict than women. The average age of the farmers was 45 years. This showed that most of the farmers are in their active age and prone to be involved in communal clashes. This agreed with the work of Okoroafor (2009) who reported that both young and middle aged farmers were involved in herdsmen crop farmers' conflicts.

Result also showed that 83.8 percent of the farmers were married; while few (13.8 percent) were single. This showed that most of the respondents were married; which conforms to the findings of Okoroafor (2009) who reported that most farmers embark on conflicts with herdsmen when their families are denied of their livelihood. Moreover, 26.9 percent of the farmers completed primary education; while only few 3.1 percent obtained Msc. The average number of years spent in formal education was 6 years. This showed that most of the crop farmers are still educationally backward. This is in consonance with Nweze (2000) who reported that education can act as a veritable tool for 


\section{International Journal of Science and Research (IJSR) ISSN (Online): 2319-7064 \\ Index Copernicus Value (2013): 6.14 | Impact Factor (2015): 6.391}

reducing and resolving farmers- herdsmen conflicts in Nigeria.

Further analysis revealed that the household size of majority (45 percent) ranged between 6 -10 persons; while few (6.9 percent) live with more than 21 persons. The average household size was 10 persons. This showed that most of the farmers have large family size. This justified the findings of Nweze (2005) that the conflicts between herdsmen and crop farmers are escalated when the crops used by farmers to feed their large household members are threatened.

The result on farm size showed that majority ( 30 percent) of the farmers cultivated between 1.1-1.5 hectares; while few 5.6 percent cultivated less than 0.50 hectare. The average farm size of the farmers is 1.6 hectare. This indicates that most of the crop farmers in the study area are still operating as small scale farmers. The result of farming experience showed that 38.8 percent of the farmers had farming experience of more than 41 years; while only 2.80 percent

Table 2: Percentage Distribution of the Socio-economic Characteristics of Fulani Herdsmen $(\mathrm{N}=16)$

\begin{tabular}{|l|l|l|l|}
\hline Socio-economic Characteristics & Frequency & Percentage & Mean $\bar{x}$ \\
\hline
\end{tabular}

\begin{tabular}{|c|c|c|c|}
\hline \multirow{2}{*}{\multicolumn{4}{|c|}{ and }} \\
\hline & $\angle$ & 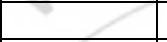 & \\
\hline Male & 16 & 100 & 7 \\
\hline \multicolumn{4}{|l|}{ Age } \\
\hline$<20$ & 2 & 12.5 & \\
\hline $21-30$ & 3 & 18.8 & \\
\hline $31-40$ & 1 & 6.3 & 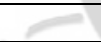 \\
\hline $41-50$ & 2 & 12.5 & 45.5 \\
\hline $51-60$ & 3 & 18.8 & \\
\hline Above 61 & 5 & 31.3 & \\
\hline \multicolumn{4}{|l|}{ Marital status } \\
\hline Single & 2 & 12.5 & \\
\hline Married & 14 & 87.5 & \\
\hline Level of education & 8 & 1 & \\
\hline No formal education & 16 & 100 & \\
\hline \multicolumn{4}{|l|}{ Household size } \\
\hline $1-5$ & 2 & 12.5 & 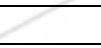 \\
\hline $6-10$ & 2 & 12.5 & 18.6 \\
\hline $11-15$ & 2 & 12.5 & \\
\hline $16-20$ & 10 & 62.5 & \\
\hline \multicolumn{4}{|l|}{ Herd size } \\
\hline $1-20$ & 2 & 12.50 & \\
\hline $21-40$ & 0 & 0.00 & \\
\hline $41-60$ & 4 & 25.00 & 68 \\
\hline $61-80$ & 2 & 12.00 & \\
\hline 81 and above & 8 & 50.00 & \\
\hline \multicolumn{4}{|l|}{ Herding experience (years) } \\
\hline$<10$ & 1 & 6.30 & \\
\hline $11-30$ & 2 & 12.50 & \\
\hline $21-30$ & 5 & 31.30 & 33 \\
\hline $\begin{array}{l}31 \text { and above } \\
\text { Herder status }\end{array}$ & 8 & 50.00 & \\
\hline On commission & 2 & 12.5 & \\
\hline Owner herder & 14 & 87.5 & \\
\hline \multicolumn{4}{|l|}{ Annual Income (N) } \\
\hline$\$ 100,000-\$ 200,000$ & 2 & 12.5 & \\
\hline$\$ 401,000-\$ 600,000$ & 2 & 12.5 & $\$ 487$, \\
\hline$\$ 601,000$ and above & 12 & 75.0 & 937.5 \\
\hline Total & 16 & 100 & \\
\hline
\end{tabular}

Source: Field Survey, 2015. were involved in farming for less than 10 years. The average farming experience of the farmers was 33 years. This shows that most of the arable crop farmers in the study area are experienced.

In addition, the result of annual farm income of the farmers showed that majority (35 percent) earned between $\$ 301,000$ - \$400,000 per annum; while the average income of the respondents was $\$ 263,000$ per annum. This indicates that most of the farmers are low income earners. This justified the work of Breusers et al., (1998) which reported that any negative influence on farmers' source of livelihood may force them out of business since most of them are low income earners.

It was further revealed that 75.60 percent of the farmers were members of cooperative societies; while 23.40 percent were not. This implies that most of the farmers belonged to cooperative societies.

Table 2 showed that all the herdsmen were males; with no formal education. Majority ( 31.3 percent) were between the ages of 41-50 years; implying that most of the herdsmen are within economically active age. This is in conformity with the findings of Peter (2002) which reported that herdsmen are violent in nature and lack formal education. Similar to this findings was that of Ofuoku (2009) who reported that Fulani herdsmen are generally violent and age does not influence their involvement in conflicts.

Further analysis indicated that 87.5 of the herdsmen were married; while few (12.50 percent) were single. This showed that most of the herdsmen were married. The household size of 62.50 percent ranged between 16-20 persons; indicating that the herdsmen have large family size.

The herd size of 50 percent was from 81 animals and above; with average herd size of 68 animals. The result of herding experience indicated that 50 percent of the herdsmen had experience of 31 years and more; while very few (12.50 percent) had herding experience of between 11-20 years. The average herding experience of the herdsmen was 33 years. Majority of the herdsmen $(87.5 \%)$ were owner herders while only $12.5 \%$ were on commission among the respondents.

The result of the annual income showed that 75 percent of the herdsmen earned more than $\$ 601,000$ per annum; whereas only few (12.50 percent) earned between $\$ 100,000$ - $\$ 200,000$ and $\$ 401,000$ - $\$ 600,000$ respectively. This shows that most of them are high income earners.

\section{Relationship between Socioeconomic Characteristics of Farmers and the Frequency of Conflicts with the Herdsmen}

Probit regression analysis was done to determine the relationship between the socioeconomic characteristics of the farmers and their frequency of conflicts with the herdsmen. The result is shown in Table 3. 


\section{International Journal of Science and Research (IJSR) \\ ISSN (Online): 2319-7064}

Index Copernicus Value (2013): 6.14 | Impact Factor (2015): 6.391

Table 3: Summary of Probit Regression Analysis

\begin{tabular}{|c|c|c|c|c|}
\hline Variables & Coefficients & S. E & t-value & Sig. \\
\hline Constant & -2.474 & 0.160 & -15.428 & $*$ \\
\hline Age & -0.002 & 0.004 & -0.615 & $* *$ \\
\hline Gender & -0.003 & 0.015 & -0.172 & $* *$ \\
\hline Marital Status & 0.034 & 0.045 & 0.741 & $* *$ \\
\hline Educational Qualification & 0.002 & 0.005 & 0.388 & NS \\
\hline Household size & 0.007 & 0.009 & 0.813 & NS \\
\hline Farm size & 0.008 & 0.012 & 0.637 & $* * *$ \\
\hline Annual income & 0.000 & 0.000 & 1.014 & $*$ \\
\hline Farming experience & 0.004 & 0.005 & 0.774 & $*$ \\
\hline Membership of org. & -0.026 & 0.031 & -0.853 & $*$ \\
\hline Chi-square & 5346.000 & & & \\
\hline
\end{tabular}

Source: Data Analysis, 2015.

$\mathrm{NS}=$ Not significant, S.E $=$ Standard Error

$*, * *$ and $* * *$ indicates significance at $1 \%, 5 \%$ and $10 \%$ level respectively.

The result of the probit analysis showed chi-square value of 5346.00. This shows the goodness- of- fit of the model. The overall model was statistically significant $(\mathrm{P}<0.05)$, implying that the independent variables exerted influence on the frequency of the conflicts with the herdsmen.

The coefficient of age $\left(\mathrm{X}_{1}\right)$ was negatively signed but statistically significant at $5 \%$. This implies that increase in age of the farmers will lead to decrease in frequency of conflict between the farmers and the herdsmen. However, the significance indicates that age is an important determinant of frequency of conflict occurrence. This is because older farmers are less prone to violence and are more experienced in conflict management, which can help reduce the frequency of conflict occurrence. This conforms to a priori expectation.

The coefficient of gender $\left(\mathrm{X}_{2}\right)$ was negatively signed but statistically significant at $5 \%$. This means that the gender composition of the farmers do not affect the frequency of conflict occurrence. The significance implies that gender is negatively associated with frequency of conflict occurrence. Marital status $\left(\mathrm{X}_{3}\right)$ was positively signed and statistically significant at $5 \%$, implying that increase in married farmers will lead to increase frequency of conflict occurrence. This however is in agreement with a priori expectation because farmers who are married tend to be good managers of conflict because of their knowledge that conflict could result to destruction of their farm investment. Also, married farmers are responsible for larger family size and more determined to defend the family means of livelihood.

Educational qualification $\left(\mathrm{X}_{4}\right)$ showed positive sign but was statistically insignificant. This implies that the higher the educational attainment of the farmers, the less the frequency of conflict. This is in line with the a priori expectation because education exposes one to knowledge and techniques of dealing with conflict rationally. Education is also useful for conflict management and reduction.

The household size $\left(\mathrm{X}_{5}\right)$ was positively related to the frequency of conflict occurrence between the farmers and the herdsmen but statistically insignificant. This means that the farmers with large household size will be more implicated in conflict occurrence. Large household size may be advantageous to the farmers as enhanced source of farm labour supply. It could also provide forces of conflicts as recalcitrant members may be willing to be involved in conflict and prove to be ready tools for perpetuating conflict. Hence, a priori expectation was met.

Farm size $\left(\mathrm{X}_{6}\right)$ was positively signed and statistically significant at $1 \%$, indicating that increase in farm size of the farmers will lead to increase in frequency of conflict occurrence between farmers and herdsmen. This is in line with a priori expectation since larger farm holdings will predispose the farms to invasion by the herds and possible confrontation with the herdsmen. The significance of this variable implies that farm size is positively associated with frequency of conflict occurrence.

Annual income $\left(\mathrm{X}_{7}\right)$ was positively signed and statistically significant at $10 \%$. This is an indication that the higher the annual income of the farmers, the higher the frequency of conflict occurrence. This is true because higher income will enable farmers to have the financial capacity to acquire equipment for prosecuting conflict and in return increase the frequency of conflict occurrence. Moreover, the indication of significance implies the annual income is an important determinant of conflict occurrence.

Farming experience $\left(\mathrm{X}_{8}\right)$ showed a positive sign and was statistically significant at $1 \%$, implying that the more experience a farmer acquires, the higher the frequency of conflict between them and the herdsmen. This falls short of a priori expectation because a well experienced farmer would have gathered expertise knowledge on how to manage conflict and prevent it from occurring. However, farming experience is positively associated with frequency of conflict occurrence as shown by the level of significance.

Membership of social organization $\left(\mathrm{X}_{9}\right)$ was negatively signed and statistically significant at $1 \%$. This imply that membership of social organization is negatively associated with frequency of conflict occurrence. This is in line with the a priori expectation. This is because farmers who belong to social organizations can easily through knowledge and information sharing in such an organization prevent and manage conflict more effectively than their counterparts who do not belong to social organizations. The final probit equation is shown below:

$\mathrm{Y}=2.474-0.002 \mathrm{~b}_{1}-0.003 \mathrm{~b}_{2}+0.034 \mathrm{~b}_{3}+0.002 \mathrm{~b}_{4}+0.007 \mathrm{~b}_{5}+$ $0.008 \mathrm{~b}_{6}+0.000 \mathrm{~b}_{7}+0.004 \mathrm{~b}_{8}-$
$(0.160)$
$(0.004)$
$(0.150)$
$(0.045) \quad(0.005)$
$(0.009)$
$(0.012) \quad(0.000) \quad(0.005)$
$0.026 b_{9}$
$(0.031)$

\section{Relationship between the Socio-economic Characteristics of the Herdsmen and the Frequency of Conflicts with Farmers}

Probit regression analysis was done to determine the relationship between the socio-economic characteristics of the herdsmen and the frequency of conflicts in the study area. The result obtained is shown in Table 4. 


\section{International Journal of Science and Research (IJSR) \\ ISSN (Online): 2319-7064 \\ Index Copernicus Value (2013): 6.14 | Impact Factor (2015): 6.391}

Table 4: Summary of Probity Regression Analysis

\begin{tabular}{|l|l|l|l|l|}
\hline Variables & Coefficients & $\mathrm{S} . \mathrm{E}$ & t-value & Sig. \\
\hline Constant & -1.188 & 1.240 & -0.958 & $*$ \\
\hline Age $\left(\mathrm{X}_{1}\right)$ & 0.034 & 0.042 & 0.811 & $\mathrm{NS}$ \\
\hline Marital Status $\left(\mathrm{X}_{2}\right)$ & -0.002 & 0.043 & -0.015 & $\mathrm{NS}$ \\
\hline Educational Level $\left(\mathrm{X}_{3}\right)$ & -0.154 & 0.470 & 0.329 & $\mathrm{NS}$ \\
\hline Sex $\left(\mathrm{X}_{4}\right)$ & -0.020 & 0.030 & -0.660 & $\mathrm{NS}$ \\
\hline Household size $\left(\mathrm{X}_{5}\right)$ & 0.047 & 0.082 & 0.576 & $\mathrm{NS}$ \\
\hline Herder status $\left(\mathrm{X}_{6}\right)$ & -0.045 & 0.174 & -0.259 & $* * *$ \\
\hline Annual income $\left(\mathrm{X}_{7}\right)$ & -0.129 & 0.287 & -0.441 & $* *$ \\
\hline Herds size $\left(\mathrm{X}_{8}\right)$ & -0.000 & 0.287 & -1.200 & NS \\
\hline Herding experience $\left(\mathrm{X}_{9}\right)$ & -0.012 & 0.000 & -0.274 & NS \\
\hline Chi-square & 1283.124 & 0.045 & & \\
\hline t-value & 0.001 & & & \\
\hline
\end{tabular}

Source: Data Analysis, 2015.

$* * *$ and $* * *$ indicates significance at $1 \%, 5 \%$ and $10 \%$ respectively.

NS indicates non-significance. S.E $=$ Standard Error.

The result of probit analysis shows that the overall model was statistically significant $(\mathrm{P}<0.05)$. This is an indication that the independent variables were important predictors of frequency of conflicts. The large chi-square value (1283.124) confirms the goodness-of-fit of the model.

Age $\left(\mathrm{X}_{1}\right)$ was positively signed but statistically insignificant. This is an indication that the older the herdsmen grew in years, the higher their frequency of conflict with farmers. This is a departure from a priori expectation because older herdsmen are supposed to have gained knowledge and experiences that can support their capacity to manage conflicts more effectively and take steps to reduce the frequency of conflicts occurrence between farmers and the herdsmen.

Marital status $\left(\mathrm{X}_{2}\right)$ was negatively signed and statistically insignificant, implying that the marital status of the herdsmen do not affect their frequency of conflicts with farmers. However, married couples tend to be more cautious when it comes to issue of conflicts so as to avoid loss of both lives and livestock.

Level of education $\left(\mathrm{X}_{3}\right)$ showed negative coefficient but statistically significant at $1 \%$. This means that the more education the herdsmen acquire, the less their frequency of conflicts with the farmers. The role of education in conflicts management has been documented in several studies. It is also in recognition of this that the Federal Ministry of Education instituted nomadic education to provide quality education to herdsmen and their households as a means of improving literacy and developing their minds towards engendering peaceful coexistence among farmers and the herdsmen. The significance of this variable is an indication that level of education is an important determinant of conflict prevention and management.

Sex $\left(\mathrm{X}_{4}\right)$ was negatively signed and statistically insignificant. This implies that being male or female does not affect the frequency of conflicts with farmers in the area. This may not be true as it is the male folks that are engaged in cattle rearing while the females are mostly engaged in milk processing and marketing. However, the influence of this variable is statistically insignificant.
In addition, household size $\left(\mathrm{X}_{5}\right)$ was positively signed and statistically insignificant. This implies that increase in the household size of the herdsmen will lead to increase in the frequency of conflict with farmers. This agreed with Okoroafor (2009) who reported that due to the large number of persons in each Fulani household, they are easily moved to fight when they have misunderstanding with farmers.

Herder status $\left(\mathrm{X}_{6}\right)$ was negatively signed but statistically significant at $10 \%$. This implies an inverse relationship between herder status and frequency of conflicts with farmers. In other words, the status of the herders either as hired or owner-herder has no relationship with frequency of conflicts occurrence with the farmers.

Annual income $\left(\mathrm{X}_{7}\right)$ of the herdsmen was negatively signed but statistically significant at $5 \%$. This implies that the higher the income of the herdsmen per annum, the less the frequency of conflict occurrence with the farmers in the area. While herd size $\left(\mathrm{X}_{8}\right)$ was negatively signed and statistically insignificant. This is an indication that the higher the herd size of the herdsmen, the less the frequency of conflicts. This however is contrary to a priori expectation because large herd size has been identified to be responsible for several conflicts.

Herding experience $\left(\mathrm{X}_{9}\right)$ was negatively signed and statistically insignificant, indicating that the more experience in years the herdsmen acquires the less the frequency of conflicts with the farmers and vice versa in the area. This conforms to the a priori expectation because experience acquired over the years will play a significant role in conflict management. However, the results of herd size and herding experience are statistically insignificant. The final probit equation is stated below:

$\mathrm{Y}=-1.188+0.034 \mathrm{~b} 1-0.002 \mathrm{~b} 2+0.154 \mathrm{~b} 3-0.020 \mathrm{~b} 4+0.047 \mathrm{~b} 5-$ $0.045 \mathrm{~b} 6-$
$(1.240)(0.042)(0.430)$
$(0.174)$
$0.126 \mathrm{~b} 7+0.000 \mathrm{~b} 8-0.012 \mathrm{~b} 9$
$(0.287)(0.000)(0.045)$

$(0.470)$

$(0.030)$

$(0.082)$

Socio-economic Effects of Farmers - Herdsmen Conflicts The study sought to find out the socio-economic effects of the farmers -herdsmen conflicts on both sides in the past five years. The results are presented in Table 5 and 6 . 


\section{International Journal of Science and Research (IJSR) \\ ISSN (Online): 2319-7064 \\ Index Copernicus Value (2013): 6.14 | Impact Factor (2015): 6.391}

Table 5: The Socio-economic Effects of Farmers Herdsmen Conflicts on the Farmers

\begin{tabular}{|c|c|c|}
\hline Socio-economic Effects & Frequency & Percentage \\
\hline \multicolumn{3}{|l|}{ Loss of lives } \\
\hline None & 159 & 99.4 \\
\hline One & 1 & 0.6 \\
\hline \multicolumn{3}{|l|}{ Sustenance of injury } \\
\hline None & 143 & 89.4 \\
\hline One & 17 & 4.4 \\
\hline Two & 5 & 3.1 \\
\hline Three & 2 & 1.3 \\
\hline Four & 3 & 1.9 \\
\hline \multicolumn{3}{|l|}{ Destruction of crops } \\
\hline None & 29 & 18.1 \\
\hline Yam & 49 & 30.6 \\
\hline Rice & 88 & 55.0 \\
\hline Cassava & 94 & 88.8 \\
\hline Vegetables & 16 & 10.0 \\
\hline Others & 6 & 3.8 \\
\hline \multicolumn{3}{|l|}{ Quantity of crops lost } \\
\hline More than $1 / 2$ of the crops & 62 & 47.3 \\
\hline About $1 / 2$ of the crops & 31 & 23.7 \\
\hline More than $1 / 2$ of the crops & 15 & 11.5 \\
\hline Almost all the crops & 16 & 12.2 \\
\hline All of the crops & 7 & 5.3 \\
\hline Social Cost & 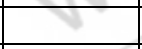 & \\
\hline $\begin{array}{l}\text { The conflict led to the breakdown of } \\
\text { peace among farmers \& herdsmen }\end{array}$ & 136 & 85.0 \\
\hline $\begin{array}{c}\text { Conflict led to perpetual fear among } \\
\text { farmers }\end{array}$ & 53 & 33.1 \\
\hline $\begin{array}{l}\text { Conflict led to the abandonment of crop } \\
\text { farm }\end{array}$ & 21 & 13.1 \\
\hline Conflict led to damage/loss of crops & 148 & 92.5 \\
\hline Breakdown of established friendship & 132 & 82.5 \\
\hline
\end{tabular}

\section{Source: Field Survey, 2015.}

The result of socio-economic effects of farmers -herdsmen conflicts showed that only 0.6 percent of the farmers had lost a family member within the period of the study. This supports the assertion of Nweze (2005) who reported that in view of the activities of Fulani herdsmen, many farmers and herdsmen have lost their lives and herds; while others have experienced dwindling production in their herds and crops; while 89.4 percent of the farmers' family members did not sustain any injury as a result of the conflict.

Few families recorded injury of one to four family members within the period.

Further analysis revealed that 88.8 percent of the crops destroyed was cassava. About 55 percent was rice; while 30.6 percent was yam. It was only 18.1 percent of the crop farmers did not have any of their crops destroyed. Moreover, 47.3 percent of the farmers lost more than $1 / 4$ of their crops; while 23.7 percent lost about $1 / 2$ of all their crops during the period; 12.2 percent of the farmers lost almost all their crops and 5.3 percent lost all their crops due to farmers- herdsmen conflicts. This is a fair reflection of the finding of Okorafor (2009) who stated that most of the farmers lost almost all their rice crops in conflict between rice farmers -herdsmen in 2008 at Amasiri, Ebonyi State.

Result further showed the major effects of the conflicts on the farmers was loss of crops ( 92.5 percent). Other social cost of the conflict include breakdown of peace and co- existence among farmers and herdsmen ( 85.0 percent) and breakdown of established friendship with herdsmen $(82.5$ percent). This is similar to the work of Tonah (2006) who reported that the conflicts between herdsmen and farmers as a threat to peace and national stability and also has implication for tribal co-existence.

Table 6: The socio-economic effects of farmers -herdsmen conflicts on the herdsmen

\begin{tabular}{|c|c|c|}
\hline \multirow{2}{*}{$\begin{array}{c}\text { Socio-economic Effects } \\
\text { Loss of lives }\end{array}$} & \multicolumn{2}{|c|}{ Frequency Percentage } \\
\hline & & \\
\hline None & 14 & 87.5 \\
\hline One & 2 & 12.5 \\
\hline \multicolumn{3}{|c|}{ Sustenance of injury by family members } \\
\hline None & 3 & 18.8 \\
\hline One & 3 & 18.8 \\
\hline Two & 4 & 25 \\
\hline Three & 4 & 25 \\
\hline Four and above & 2 & 12.5 \\
\hline \multicolumn{3}{|l|}{ Loss of livestock } \\
\hline \multicolumn{3}{|l|}{ Sheep } \\
\hline None & 7 & 43.7 \\
\hline $5 . / 2$-Jan & 9 & 56.3 \\
\hline \multicolumn{3}{|l|}{ 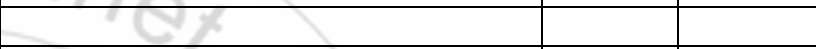 } \\
\hline Cattle & & \\
\hline None & 2 & 12.5 \\
\hline 5-Jan & 5 & 31.3 \\
\hline 10-Jun & 9 & 56.3 \\
\hline \multicolumn{3}{|c|}{ Sustenance of Injury by livestock } \\
\hline Sheep & & \\
\hline None & 7 & 43.8 \\
\hline 3-Jan & 3 & 18.8 \\
\hline 6-Apr & 2 & 12.5 \\
\hline 9-Jul & 2 & 12.5 \\
\hline 10 and above & 2 & 12.5 \\
\hline$\sqrt{1}$ & & \\
\hline Cattle & & \\
\hline 3-Jan & 2 & 12.5 \\
\hline 6-Apr & 4 & 25 \\
\hline 9-Jul & 6 & 37.5 \\
\hline 10 and above & 4 & 25 \\
\hline
\end{tabular}

\section{Cost of livestock lost}

\begin{tabular}{|c|c|c|c|c|}
\hline Sheep & Frequency & Percentage & Avg.Cost & Total cost \\
\hline $1-5$ & 9 & 56.3 & 11,944 & $\begin{array}{c}11944- \\
59,720\end{array}$ \\
\hline Cattle & & & & \\
\hline $1-5$ & 5 & 31.3 & 1129,000 & $\begin{array}{c}1129,000- \\
645,000\end{array}$ \\
\hline $6-10$ & 56.3 & 146,666 & $\begin{array}{c}1879,996- \\
1,466,660\end{array}$ \\
\hline Social cost & $\begin{array}{l}\text { Break down of peace and tribal } \\
\text { Co-existence among herdsmen }\end{array}$ & 14 & 87.5 & \\
\hline $\begin{array}{c}\text { Conflict led to perpetual fear } \\
\text { among }\end{array}$ & & 14 & 87.5 & \\
\hline \multicolumn{2}{|c|}{ Herdsmen } & 16 & 100 & \\
\hline $\begin{array}{c}\text { Conflict led to migration of } \\
\text { herdsmen }\end{array}$ & 16 & 100 & \\
\hline $\begin{array}{c}\text { Conflict led to reduction of herd } \\
\text { size }\end{array}$ & 13 & 81.3 & \\
\hline $\begin{array}{c}\text { Breakdown of established } \\
\text { friendship }\end{array}$ & 13 & $\mathbf{1 0 0}$ & \\
\hline Total & $\mathbf{1 6}$ & & \\
\hline
\end{tabular}

Source: Field Survey, 2015. 


\section{International Journal of Science and Research (IJSR) \\ ISSN (Online): 2319-7064}

Index Copernicus Value (2013): 6.14 | Impact Factor (2015): 6.391

The study indicated that $12.5 \%$ of herdsmen lost lives of a family member as a result of the conflicts. Moreover, 50\% of the herdsmen indicated that two or three of their family members sustained various degrees of injury during the period covered by the study. The results equally showed that $12.5 \%$ of the herdsmen had four or more members of their families injured in the course of the conflicts. This is in line with the findings of Okereke (2008) who indicated that many farmers and herdsmen have lost their lives, crops and herds and pointed that these frequent clashes may bring about tribal disintegration and instability of the nation.

Further investigation revealed that $56.3 \%$ of the herdsmen lost between 6-10 cattle and 1-5 sheep. It was only $12.5 \%$ of the herdsmen that did not lose any cattle.

Sustenance of injury arising from conflicts was more prevalent in cattle than sheep

The study further revealed that $56.3 \%$ of the herdsmen incurred average loss of $\$ 35,832.00$; whereas $64.3 \%$ lost an average of $1,173,328.00$ worth of their cattle; while $35.7 \%$ incurred an average loss of $\$ 387.000 .000$. This is closely related to the work of Jonah (2006) who asserted that huge resources of both farmers and herdsmen are wasted during the course of conflicts among the two groups. Most farmers and herdsmen lost huge sum of money due to the conflicts between them (Delta State Ministry of Agriculture, 2000).

The major perceived social implications of the conflicts by the herdsmen include loss of peace and co-existence with crop farmers $(87.5 \%)$, the herdsmen lived in perpetual fear due to the conflicts $(87.5 \%)$, the conflicts led to their migration and also the reduction of number of cattle produced $(100 \%)$ and the breakdown of established friendship (81.3\%). This finding conforms to Berry (2002) assertion that the conflicts sometimes led to break down of peace and business transaction among the two groups.

\section{Conclusion and Recommendations}

The outcome of this study had shown that arable crop farmers and Fulani herdsmen conflicts in Ebonyi State has been a serious threat to agricultural productivity and source of insecurity in the area. Incidences of such conflicts had enormous social and economic implications on both the farmers and the Fulani herdsmen. Food security among the farm household has been seriously threatened while the herders' cattle were endangered and with huge financial loss. The conflicts had also threatened peace and tribal coexistence between the two groups as well as caused a breakdown of already established friendship ties among the people. It is recommended that a joint peace and conflict resolution committee that is made up of the leadership of the farm community and the herders be constituted by the state government while the educational status of the herdsmen needs to be improved to appreciate the vulnerability of unsustainable exploitation of natural resources to vagaries of climate change.

\section{References}

[1] Adebayo, A (1997). Contemporary dimensions of migration among historically migrant Nigerians. Journal of Asian African Studies. 32 PP:93-109.

[2] Bermadet, P (1999). Peuls en conflits en moyenne et haute cot d Ivoire de 1950 a (1990). PP :407-444.

[3] Blench, R. M (1994). The expansion and adaptation of Fulani pastoralism to sub-humid condition in Nigeria. PP:197-213.

[4] Breusers M. (1998). Conflict or symbiosis? Disentangling farmer-herdsmen relationship: The Mossi and Fulani of the Central Plateau PP:357-380.

[5] Delta State Ministry of Agriculture (2000). Agricultural Statistical Information, Asaba Delta State, Nigeria.

[6] Eastwood, R., Kirsten, J and Lipton, M (2006). Premature Deagriculturazation? Land Inequality and Rural Dependency in Limpopo Province, South Africa. Journal of Development Studies, 41325-1349.

[7] Ebii, C.O (2004). Farming system and bush fire culture, an environmental issue in Ishiagu, Ebonyi State, Nigeria. Proceedings of the academic seminar series o Federal College of Agriculture vol.1,1215.

[8] Fasona, M.J and Omojola, T (2005). Climate Change, Human Security and Communal Clashes in Nigeria. Paper at International Workshop in Human Security and Climate Change, Holmen Ford Hotel, Oslo Oct. 21-23, 2005, Pp.3-13.

[9] Gefu, J.O and Kolawo, A (2002). Conflict in Common Property Resource Use: Experiences from an irrigation project. Paper prepared for $9^{\text {th }}$ Conference of the International Association for the study of common property. Indiana. Retrieved on $14^{\text {th }}$ October, 2005 from http: // d/c.dlib. Indiana. Edu/achive/00000823/00/gefuj080502.pdf

[10] Nweze, N.J (2005). Minimizing Farmer-helder conflict in Fadama Areas through Local Development Plans: Implication for Increased Crop-livestock productivity in Nigeria Society for Animal Production, held $20^{\text {th }}$. $24^{\text {th }}$ March.

[11] Ofuoku, A.U (2009). Causes, Effects and resolution of farmers-nomadic cattle herders conflict in Delta State, Nigeria. Online http/www.academicjournals.org/ijsa.june 172009:4754.

[12] Okoroafor, O (2009). Annual report in the office of the Director Livestock and Fisheries; Ministry of Agriculture and Natural Resources, Ebonyi State, Nigeria. Pp: 120-231.

[13] Peter W. (2002). Understanding Conflict Resolution: war; peace and the Global System. London: Sage Publishing 2002.PP:16-17.

[14] Tonah, S (2006). Managing Farmer-Herder Conflict in Ghana's Volta Basin, Ibadan Journal of Social Science 4 (1):33-65. 